\title{
KORELASI ANTARA PEKERJAAN SUAMI DENGAN KEHARMONISAN KELUARGA PADA KARYAWAN PERUSAHAAN PT. ASMIN KOALINDO TUHUP DI KELURAHAN MUARA TUHUP
}

\author{
Mitral* \\ Sanawiah $^{2 *}$ \\ I*Mahasiswa Pasca Sarjana IAIN Palangkaraya Kalimantan Tengah, Indonesia \\ Email: aiysayyidhan@gmail.com/nadz_8624@yahoo.co.id \\ 2*Dosen Universitas Muhammadiyah Palangkaraya \\ Email : Sanaw10@yahoo.co.id
}

\begin{abstract}
A happy and harmonious family is a dream for every person, harmonious family in the community is also known as Sakinah, mawaddah, warahmah, as mentioned in article 45 of Law No.I of 1974 concerning marriages mentions that the purpose of marriage is to form a happy and eternal family (household) based on belief in the one supreme God, while in chapter 3 in the Compilation of Islamic Law states that marriage aims to bring a household life becoming sakinah, mawaddah and rahmah, this needs to be obtained and performed in every family life. Otherwise, the success of family harmony could have been caused by a husband's job, then, the study entitled "The Correlation Between Husband's Job and Life Families Harmony in Company Employees of PT Asmin Koalindo Tuhup in the MuaraTuhup village ".

There are two issues in this study: (I) how is the family harmony as the employees of PT Asmin Koalindo Tuhup in the Muara Tuhup village; (2) how is the connection between husband's work as employees of PT Asmin Koalindo Tuhup in Muara Tuhup village with family harmony. This research aims to find deeper some factors that influence family harmony employees of PT Asmin Koalindo Tuhup in the Muara Tuhup Village, to measure the relevance between the husband's job as an employee of PT Asmin Koalindo Tuhup with family harmony in the village of Muara Tuhup.

The research approach in this study use quantitative research with the number of samples employees and his wife are 22 people. To collect the data is using questionnaire. Data analysis is using Product Moment correlation with some steps are editing, coding, tabulating, analyzing and interpretation. The study result showed that the position/line of work in PT Asmin Koalindo Tuhup includes the Administrative Office, supervisors, drivers, security, and cleaning service. As for family harmony of married couples showed harmonic levels as much as I sample, quite harmonious was 8 samples and 2 samples for less harmonious.

Based on statistical analysis test correlation was tested by $t$ test calculations and tobe calculated as the Coefficient of Determination expresses that there is a correlation between the husband's job with the harmony of the family, the husband's job gave a strong influence on family harmony, it means the hypothesis in this research, $\mathrm{Ho}$ is rejected and $\mathrm{Ha}$ is accepted.
\end{abstract}

Keywords: correlation, husband's line of job, family harmony

\section{ABSTRAK}

Keluarga yang bahagia dan harmonis merupakan dambaan bagi setiap orang, keluarga yang harmonis dikenal juga di masyarakat dengan sebutan sakinah, mawaddah, warahmah, sebagaimana disebutkan dalam pasal 45 Undang-Undang No I Tahun 1974 tentang perkawinan menyebutkan tujuan perkawinan adalah membentuk keluarga (rumah tangga) yang bahagia dan kekal berdasarkan Ketuhanan Yang Maha Esa, sedangkan pada pasal 3 dalam Kompilasi Hukum Islam menyebutkan bahwa perkawinan bertujuan untuk mewujudkan kehidupan rumah tangga yang sakinah, mawaddah dan rahmah, hal ini perlu kita peroleh dan dilakukan dalam setiap kehidupan berkeluarga. Keberhasilan keharmonisan keluarga bisa saja disebabkan oleh pekerjaan suami, penelitian yang berjudul "Korelasi Antara Pekerjaan Suami Dengan Keharmonisan Keluarga Pada Karyawan Perusahaan PT Asmin Koalindo Tuhup di Kelurahan Muara Tuhup".

Ada dua permasalahan dalam penelitian ini yaitu: (I) bagaimana keharmonisan keluarga karyawan perusahaan PT Asmin Koalindo Tuhup di Kelurahan Muara Tuhup; (2) bagaimana hubungan pekerjaan suami karyawan perusahaan PT Asmin Koalindo Tuhup di Kelurahan Muara Tuhup dengan keharmonisan keluarga?. Tujuan penulisan ini untuk menggali lebih dalam faktor-faktor apa saja yang mempengaruhi keharmonisan keluarganya, mengukur relevansi antara pekerjaan suami sebagai karyawan perusahaan PT Asmin KoalindoTuhup dengan keharmonisan keluarga.

Pendekatan penelitian dalam penelitian ini adalah menggunakan penelitian kuantitatif, dengan jumlah sampel karyawan dan istrinya sebanyak 22 orang. Penggalian data menggunakan angket. Analisis data menggunakan teknik korelasi Product Moment dengan langkah-langkah editing, coding, tabulating, analizing dan interpretating. Hasil penelitian menunjukkan bahwa posisi/bidang pekerjaan di PT Asmin Koalindo Tuhup antara lain Administrative Office, supervisor, Driver, security, dan cleaning service. Adapun keharmonisan keluarga pada pasangan suami istri menunjukkan tingkat harmonis sebanyak I sampel, cukup harmonis 8 sampel dan kurang harmonis 2 sampel. Berdasarkan uji statistik analisis korelasi dan diuji dengan perhitungan uji t serta dihitung dengan rumus Koefisien Determinasi menunjukkan terdapat korelasi antara pekerjaan suami dengan keharmonisan keluarga, pekerjaan suami memberi pengaruh yang cukup kuat terhadap keharmonisan keluarga hal ini berarti hipotesis dalam penelitian ini Ha diterima dan Ho ditolak. Kata kunci: Korelasi, Pekerjaan Suami, Keharmonisan Keluarga. 


\section{PENDAHULUAN}

\begin{abstract}
Agama Islam merupakan ajaran yang di wahyukan kepada Nabi Muhammad SAW, membawa misi rahmatan lil alamin (rahmat bagi seluruh alam), dalam ajaran agama Islam terdapat beberapa syariat yang di tujukan kepada pemeluknya untuk diamalkan. Salah satu dari bagian syariat Islam adalah syariat tentang Ahwal Syakhsyiyah yaitu bagian menyangkut hubungan keluarga yang didalamnya membahas mengenai pernikahan.

Proses lahirnya sebuah keluarga atau rumah tangga dimulai dari hasrat dan keinginan individu untuk membina rumah tangga antar individu dengan individu yang lainnya, hasrat itu merupakan fitrah yang dibawa sejak individu itu lahir. Menurut Soerjono Soekanto sebagaimana dikutip Atang Abdul Hakim dan Jaih Mubarak (2000:213) mengatakan bahwa hasrat manusia sejak dilahirkan adalah: pertama, menjadi satu dengan manusia lain di sekelilingnya; kedua, menjadi satu dengan suasana alam sekelilingnya. Oleh karena itu, terbentuknya sebuah kaluarga diawali dengan proses memilih yang akan dilakukan oleh individu yang berlainan jenis kelamin, lalu melamar (khithbah), dan diakhiri dengan perkawinan (alnikah)
\end{abstract}

Nabi Muhammad Saw memprioritaskan dalam menikahi perempuan hendaklah memilihnya pada perempuan yang kuat agamanya karena hal itu dapat menyelamatkan kita di kemudian hari, dan tiga kriteria sebelumnya memungkinkan untuk kita dapatkan apabila mendahulukan agamanya. Seperti yang dikemukakan oleh A. Mukti Ali sebagaimana dikutip oleh Abdul Manan (2008: 2) ketika menjabat sebagai Menteri Agama RI dalam ceramahnya yang disampaikan pada kursus PB4 yang diselenggarakan oleh BP4 Pusat di Masjid Sunda Kelapa Jakarta, antara lain mengemukakan bahwa kalau seorang bertanya bagaimana cara membangun negara yang kuat, maka jawab ialah negara yang kuat dibangun dari rumah tangga yang kuat, negara yang adil dibangun dari rumah tangga yang adil, negara yang makmur dibangun dari keluarga yang makmur. Jadi, kalau ingin membangun negara, maka sebaiknya harus dibangun keluarga terlebih dahulu dengan sebaik-baiknya, tanpa membangun keluarga dengan sebaik-baiknnya maka mustahil akan tercapai pembangunan negara yang sedang dilaksanakan ini.

\section{Menurut Muhammad Dlaifurrahman}

(2017: 4I) dalam jurnalnya mengatakan dalam sebuah keluarga ada hak dan kewajiban dari masingmasing pihak yang berarti memahami dan menyadari apa yang menjadi hak dan kewajibannya. Seorang suami berhak mendapatkan perhatian, kasih sayang, pelayanan seksual dan rumah tangga dari sang istri, demikian juga dengan sang istri. Hanya saja istri memiliki hak yang tidak dimiliki suami, yaitu hak diberi nafkah. Sementara kewajiban suami terhadap istrinya adalah memberi nafkah, mencukupi pakaiannya dan mempergauli istri dengan baik lahir dan batin. Sedangkan kewajiban keduanya adalah memenuhi apa yang menjadi hak pasangannya. Kewajiban suami memenuhi hak-hak istrinya, demikian juga kewajiban istri adalah memenuhi kewajiban suaminya.

Seorang suami atau ayah mempunyai tanggung jawab terhadap keluarga yang dipimpinnya, laki-laki sebagai seorang muslim juga mempunyai tugas yang merupakan tugas pokok setiap muslim atau mu'min yaitu melakukan amar ma'ruf nahi mungkar. Sebagai pemimpin keluarga, seorang suami atau ayah mempunyai tugas dan kewajiban yang tidak ringan yaitu memimpin keluarganya. Dia adalah orang yang bertanggung jawab terhadap setiap individu dan apa yang berhubungan dengannya dalam keluarga tersebut, baik yang berhubungan dengan jasadiyah, ruhiyah, maupun aqliyahnya. Maksud jasadiyah atau yang identik dengan kebutuhan lahiriyah antara lain seperti kebutuhan sandang, pangan, tempat tinggal, ataupun yang sifatnya sosial seperti kebutuhan berinteraksi dengan sesamanya dan lain sebagainya. sedangkan kebutuhan yang berhubungan dengan ruhiyah seperti kebutuhan beragama, kebutuhan aqidah atau kebutuhan tauhid. Kemudian selanjutnya adalah kebutuhan yang bersifat aqliyah yaitu kebutuhan akan pendidikan. Seorang suami hendaknya memperhatikan aspek keharmonisan keluarganya dalam mencari nafkah. Seorang suami dituntut untuk mengelola keluarganya secara baik. Pada sebagian masyarakat ada yang menerapkan hal tersebut. Namun, problematika yang terjadi di masyarakat Kelurahan Muara Tuhup Kabupaten Murung Raya sungguh memprihatinkan, sebagian suami tidak menunaikan kewajibannya, sibuk dengan berbagai hal keduniaan mengurus pekerjaan kemudian lalai mengurus keluarga untuk membentuk pernikahan keluarganya sesuai dengan cita-cita Islam dalam membentuk keluarga yang harmonis.

Masyarakat Kelurahan Muara Tuhup merupakan masyarakat yang majemuk, terdiri dari berbagai macam etnik suku. $\mathrm{Hal}$ ini karena terbukanya lapangan pekerjaan sebagai karyawan sebuah perusahaan tambang batu bara yang beroperasi pada daerah ini. Sehingga menjadi peluang bagi orang yang ingin meningkatkan taraf hidup untuk menjadi lebih baik dan meningkat. Suatu pekerjaan ada kalanya menjadi faktor utama dalam sebuah keluarga, pekerjaan akan menjadi suatu landasan dalam mencari nafkah untuk keluarga, banyak jenis pekerjaan yang ada pada saat sekarang ini, diantaranya adalah menjadi seorang karyawan di perusahaan-perusahaan tambang batu bara yang beroperasi di sekitar Kelurahan Muara Tuhup, salah satunya yakni PT Asmin Koalindo Tuhup. Asumsi sementara buat peneliti, bahwa ada korelasi antara sistem penetapan waktu pekerjaan dengan keharmonisan rumah tangga bagi warga Muara Tuhup. Bila asumsi peneliti benar, maka tentu hal ini sangat memprihatinkan, sebab dengan adanya 
penghasilan yang memadai seharusnya menjadi faktor penting untuk menggapai keharmonisan sebuah keluarga, kemungkinan lain bisa menjadi faktor keharmonisan seperti strata pendidikan, psikologi, lingkungan dan lain-lain. Rumusan masalah yang diajukan pada penelitian ini adalah bagaimana hubungan pekerjaan suami karyawan Perusahaan PT Asmin Koalindo Tuhup di Kelurahan Muara Tuhup dengan keharmonisan keluarga, sedangkan tujuan penelitian ini untuk mengukur relevansi antara pekerjaan suami karyawan Perusahaan PT Asmin Koalindo Tuhup dengan keharmonisan keluarga di Kelurahan Muara Tuhup. Penelitian ini dilaksanakan di Kelurahan Muara Tuhup Kabupaten Murung Raya Provinsi Kalimantan Tengah.

\section{KAJIAN \\ TEORI}

I.
Kor
elasi

Menurut Anas Sudijono (2008: 179) kata "korelasi" berasal dari bahasa inggris correlation. Dalam bahasa Indonesia sering diterjemahkan dengan "hubungan", atau "saling hubungan", atau "hubungan timbal-balik." Dalam Ilmu Statistik Istilah "korelasi" diberi pengertian sebagai "hubungan antardua variabel atau lebih". Hubungan antardua variabel dikenal dengan istilah: bivariate correlation, sedangkan hubungan antarlebih dari dua variabel disebut multivariate correlation.

Korelasi berasal dari kata ko yang berarti saling dan relasi yang berarti hubungan, sehingga korelasi berarti saling berhubungan. Dua hal atau lebih dikatakan mempunyai saling hubungan apabila diantara mereka terdapat kesejajaran nilai. Kesejajaran nilai mengandung arti bahwa bervariasinya suatu gejala diikuti bervariasinya gejala yang lain. Misalnya: bertambahnya jumlah barang dipasar berhubungan dengan menurunnya harga barang tersebut, meningkatnya pendapatan berhubungan dengan meningkatnya tabungan masyarakat, dan sebagainya.

Korelasi merupakan teknik analisis yang termasuk dalam salah satu teknik pengukuran asosiasi / hubungan (measures of association). Pengukuran asosiasi merupakan istilah umum yang mengacu pada sekelompok teknik dalam statistik bivariat yang digunakan untuk mengukur kekuatan hubungan antara dua variabel. Diantara sekian banyak teknik-teknik pengukuran asosiasi, terdapat dua teknik korelasi yang sangat populer sampai sekarang, yaitu Korelasi Pearson Product Moment dan Korelasi Rank Spearman. Selain kedua teknik tersebut, terdapat pula teknik-teknik korelasi lain, seperti Kendal, Chi-Square, Phi Coefficient, GoodmanKruskal, Somer, dan Wilson. Sedangkan dalam buku karangan Arief Fuchan sebagaimana dikutip dalam blog nurmyassuffah (diakses: 5 September 2013) menyatakan bahwa tehnik penelitian korelasi merupakan tehnik statistik untuk menentukan hubungan antara pasangan skor.

Adapun pada penelitian ini, yang ingin diteliti adalah apakah ada hubungan pekerjaan suami dengan keharmonisan keluarga yang digambarkan dengan indeks statistik yang dikenal dengan koefisien korelasi.

\section{Keharmonisan Keluarga}

\section{I) Pengertian Keharmonisan Keluarga}

Dalam buku kamus besar bahasa indonesia (1989: 299) secara terminologi keharmonisan berasal dari kata harmonis yang berarti serasi, selaras. Titik berat dari keharmonisan adalah keadaan selaras atau serasi. Keharmonisan bertujuan untuk mencapai keselarasan dan keserasian dalam kehidupan. Keluarga perlu menjaga kedua hal tersebut untuk mencapai keharmonisan. Basri (1996:III) mengatakan keluarga yang harmonis dan berkualitas yaitu keluarga yang rukun bahagia, tertib, disiplin, saling menghargai, penuh pemaaf, tolong menolong dalam kebajikan, memiliki etos kerja yang baik, bertetangga

dengan saling menghormati, taat mengerjakan ibadah, berbakti pada yang lebih tua, mencintai ilmu pengetahuan, dan memanfaatkan waktu luang dengan hal yang positif dan mampu memenuhi dasar keluarga. Pendapat senada juga dikemukakan oleh Qaimi (2002:14) bahwa keluarga harmonis merupakan keluarga yang penuh dengan ketenangan, ketentraman, kasih sayang, keturunan dan kelangsungan generasi masyarakat, belas- kasih dan pengorbanan, saling melengkapi, dan menyempurnakan, serta saling membantu dan bekerja sama". Selain itu, Drajat (1975: 9) juga berpendapat bahwa keluarga yang harmonis atau keluarga bahagia adalah apabila kedua pasangan tersebut saling menghormati, saling menerima, saling menghargai, saling mempercayai, dan saling mencintai.

Dlori (2005:30-32) berpendapat keharmonisan keluarga adalah bentuk hubungan yang dipenuhi oleh cinta dari kasih, karena kedua hal tersebut adalah tali pengikat keharmonisan. Kehidupan keluarga yang penuh cinta kasih tersebut dalam Islam disebut sakinah-mawaddah- warahmah. Yaitu keluarga yang tetap menjaga perasaan cinta; cinta terhadap suami/istri, cinta terhadap anak, juga cinta pekerjaan. Perpaduan cinta suami-istri ini akan menjadi landasan utama dalamberkeluarga. Islam menganjarkan agar suami memerankan tokoh utama dan istri memerankan peran lawan yaitu menyeimbangkan karakter suami. Dari beberapa definisi tentang keharmonisan keluarga yang dikemukakan para tokoh, dapat disimpulkan keharmonisan keluarga adalah keadaan keluarga di mana para anggotanya merasa bahagia, saling 
mencintai dan saling menghormati serta dapat mengaktualisasikan diri sehingga perkembangan anggota keluarga berkembang secara normal.

\section{2) Faktor-Faktor yang Mempengaruhi Keharmonisan Keluarga}

Ada banyak ahli yang mengemukakan tentang faktor-faktor yang mempengaruhi keharmonisan keluarga, di bawah ini akan dikemukakan beberapa faktor yang mempengaruhi keharmonisan keluarga menurut para ahli. Menurut Sarlito Wirawan Sarwono (1982:79) dalam bukunya menyatakan Keluarga harmonis atau keluarga bahagia adalah apabila dalam kehidupannya telah memperlihatkan faktor- faktor berikut:

I. Faktor kesejahteraan jiwa. Yaitu rendahnya frekwensi pertengkaran dan percekcokan di rumah, saling mengasihi, saling membutuhkan, saling tolong-menolong antar sesama keluarga, kepuasan dalam pekerjaan dan pelajaran masing-masing dan sebagainya yang merupakan indikator- indikator dari adanya jiwa yang bahagia, sejahtera dan sehat.

2. Faktor kesejahteraan fisik. Seringnya anggota keluarga yang sakit, banyak pengeluaran untuk kedokter, untuk obat-obatan, dan rumah sakit tentu akan mengurangi dan menghambat tercapainya kesejahteraan keluarga.

3. Faktor perimbangan antara pengeluaran dan pendapatan keluarga. Kemampuan keluarga dalam merencanakan hidupnya dapat menyeimbangkan pemasukan dan pengeluaran dalam keluarga.

Sedangkan Singgih D Gunarsa dan Yulia Singgih D. Gunarsa (199I: 202-203) mengemukakan bahwa membina rumah tangga akan berhasil tergantung dari penyesuaian antara kedua belah pihak dan bagaimana mengatasi kesulitankesulitan,

maka kedua belah pihak harus memperhatikan:

I. Menghadapi kenyataan. Suami istri perlu menghadapi kenyataan hidup dari semua yang terungkap dan tersingkap sebagai suatu tim, dan menanggulanginya dengan bijaksana untuk menyelesaikan masalah.

2. Penyesuaian timbal balik perlu usaha terus menerus dengan saling memperhatikan, saling mengungkapkan cinta kasih dengan tulus, menunjukkan pengertian, penghargaan, dan saling memberi dukungan semangat.

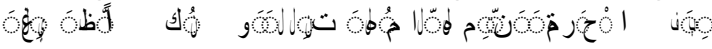

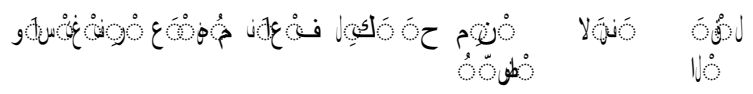

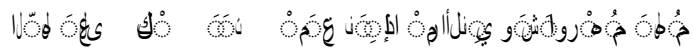

is

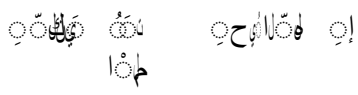

Kesemuanya berperan penting dalam memupuk hubungan yang baik, termasuk dalam hubungan yang paling intim dalam hubungan suami istri adalah seks.

3. Latar belakang suasana yang baik. Untuk menciptakan suasana yang baik, dilatar belakangi oleh pikiran-pikiran, perbuatan dan tindakan yang penuh kasih sayang. Maka macam-macam perasaan jengkel, kecewa, tidak adil

yang bisa menimbulkan prasangka curiga yang mewarnai suasana hubungan suami istri dan mempengaruhi hubungan intim mereka harus dijauhi.

Menurut Hasan Basri (2002: 27) pembentukan keluarga harmonis hendaknya diniatkan untuk menyelenggarakan kehidupan keluarga yang penuh dengan semangat sakinahmawaddah- warahmah dengan selalu mendekatkan diri kepada Allah dan mendambakan keridhaan-Nya, limpahan hidayah dan taufiq-Nya. Kehidupan keluarga yang didasari oleh niat dan semangat beribadah kepada Allah, maka keluarga yang demikian akan selalu mendapatkan perlindungan dalam mendapatkan tujuan-tujuannya yang penuh dengan keluhuran.

Kasih sayang yang tertanam dalam hati dan menjadi kelembutan dalam sikap, tindakan dan ucapan akan memberikan hamba tersebut ketenangan kalbu. Karenanya pasangan yang tingkah lakunya lembut akan mendapatkan banyak kebahagiaan dalam kehidupannya. Cinta yang berakar pada tempramen yang lembut pada siapapun yang dicintai. Begitu pula dalam keluarga, jika suami mempunyai sikap lembut pada istrinya, terhadap keluarga, terhadap masyarakat, makasuasana akan dirasa nyaman, keluarga menjadi harmonis, punya banyak teman, disukai dan dihormati oleh masyarakat. (Muhammad M. Dlori: 34-35).

Dalam AL-Quran Surat Ali-Imran ayat I59 Allah Swt berfirman: kepada-Nya." (Kementrian Agama

Berdasarkan pendapat beberapa tokoh di atas yang menyebutkan tentang faktor-faktor keharmonisan keluarga, maka dapat disimpulkan bahwa faktor

keharmonisan keluarga adalah adanya saling menghargai diantara anggota keluarga, saling menyayangi, terjaganya kesehatan rohani dan jasmani serta 
Artinya: "Maka disebabkan rahmat dari Allah-lah kamu berlaku lemah Lembut terhadap mereka. sekiranya kamu bersikap keras lagi berhati kasar, tentulah mereka menjauhkan diri dari sekelilingmu. Karena itu ma'afkanlah mereka, mohonkanlah ampun bagi mereka, dan bermusyawaratlah dengan mereka dalam urusan itu. Kemudian apabila kamu Telah membulatkan tekad, Maka bertawakkallah kepada Allah. Sesungguhnya Allah menyukai orang-orang yang bertawakkal

perekonomian yang matang.

\section{HASIL DAN PEMBAHASAN}

Penelitian ini menggunakan pendekatan kuantitatif, yaitu penelitian yang bekerja dengan angka, yang datanya berwujud bilangan (skor atau nilai, peringkat, atau frekuensi), yang dianalisis dengan menggunakan statistik untuk menjawab pertanyaan atau hipotesis penelitian yang bersifat spesifik, dan untuk melakukan prediksi bahwa suatu variabel tertentu mempengaruhi variabel yang lain oleh karena itu penelitian kuantitatif secara tipikal dikatikan dengan proses induksi enumerative yaitu menarik kesimpulan berdasarkan angka dan melakukan abstraksi berdasar generalisasi. Salah satu tujuan utamanya adalah untuk menemukan seberapa banyak karakteristik yang ada dalampopulasi induk mempunyai karakteristik seperti yang terdapat pada sampel (Asmadi alsa: 13).

Meskipun Pendekatan kuantitatif, kata-kata dalam penelitian ini menggunakan jenis penelitian deskriptif dan kesimpulan yang diambil bersifat kualitatif deskriptif. Penelitian ini dilakukan untuk memberikan gambaran yang lebih detail mengenai suatu gejala atau fenomena. dalam hal ini, jenis penelitian ini merupakan penelitian deskriptif kuantitatif yaitu penelitian tentang data yang dikumpulkan dan dinyatakan dalam bentuk angka - angka, meskipun juga berupa data kualitatif sebagai pendukungnya dengan pengambilan konklusinya seperti kata-kata atau kalimat yang tersusun dalam angket, kalimat hasil konsultasi atau wawancara antara peneliti dengan informan. Pendekatan kuantitatif digunakan untuk menguji hasil analisis dari hipotesis secara statistik, apakah ada atau tidak korelasi antara pekerjaan suami dengan keharmonisan keluarga pada karyawan perusahaan PT Asmin Koalindo Tuhup di Kelurahan Muara Tuhup. Dalam penelitian ini peneliti menggunakan jenis desain penelitian korelasional. Korelasi merupakan suatu hubungan antara satu variabel

dengan variabel lainnya. Hubungan antara variabel tersebut bisa secara korelasional bisa juga secara kausal.

Pekerjaan suami sebagai karyawan perusahaan PT Asmin Koalindo Tuhup menjadi objek yang menumbuhkan kondisi harmonis dalam keluarga, Keharmonisan keluarga maksudnya adalah terciptanya keadaan yang sinergis diantara anggotanya yang di dasarkan pada cinta kasih, dan mampu mengelola kehidupan dengan penuh keseimbangan (fisik, mental, emosional dan spiritual) baik dalam tubuh keluarga maupun hubungannya dengan yang lain, sehingga para anggotanya merasa tenteram di dalamnya dan menjalankan peran-perannya dengan penuh kematangan sikap, serta dapat melalui kehidupan dengan penuh keefektifan dan kepuasan batin. Inilah yang menjadi akibat dari terdukungnya finansial keluarga. Dalam penelitian ini, peneliti berupaya untuk mengukur indikator-indikator yang dapat diukur dalam upaya memberikan nilai atau skor, indikator ini disesuaikan dengan konsep teori yang telah dibahas pada pembahasan sebelumnya dan juga konsep teori yang berkembang pada saat sekarang, indikatorindikator ini juga akan peneliti cocokkan dengan perspektif atau pemahaman tokoh masyarakat di Kelurahan Muara Tuhup mengenai keharmonisan keluarga yang peneliti anggap dapat memberikan penilaian mengenai kelayakan indikator tersebut.Sebelum mengukur indikator dari penelitian ini terlebih dahulu akan peneliti buat skala pengukuran. Skala pengukuran merupakan kesepakatan yang digunakan sebagai acuan untuk menentukan panjang pendeknya interval yang ada dalam alat ukur, sehingga alat ukur tersebut bila digunakan dalam pengukuran akan menghasilkan data kuatitatif. (Sugiyono :133). Adapun macam- macam skala pengukuran dapat berupa : skala nominal, skala ordinal, skala interval, dan skala rasio. Dari skala pengukuran itu akan diperoleh data nominal, ordinal, interval dan ratio. Berbagai skala sikap yang dapat digunakan antara lain :

I. Skala Likert

\section{Skala Guttman}

\section{Rating Scale}

\section{Semantic Deferential}

Ke empat jenis skala tersebut bila digunakan dalam pengukuran, akan mendapatkan data interval atau rasio. Hal ini akan tergantung pada bidang yang diukur. (Sugiyono :I34) dalam penelitian ini skala pengukuran yang peneliti pilih adalah Skala Likert. Skala Likert digunakan untuk mengukur sikap, pendapat, dan persepsi seseorang atau sekelompok orang tentang fenomena sosial. Dengan skala Likert, maka variabel yang akan diukur dijabarkan menjadi indikator variabel. Kemudian indikator tersebut dijadikan sebagai titik tolak untuk menyusun item- item instrumen yang dapat berupa pernyataan atau pertanyaan. Untuk mengetahui kategori skor pekerjaan suami sebagai karyawan perusahaan PT

Asmin Koalindo Tuhup terlebih dahulu ditentukan interval skor dengan rumus:

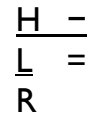


5

$\frac{5-}{\frac{5}{0.8}}=$

5 a. Sangat baik $\quad: 4,6-$

5,4 b. Baik : 3,7

- 4,5 c. Cukup baik :

2,8 - 3,6 d. Kurang baik

: 1,9 - 2,7 e. Sangat kurang

baik: I- I,8

Sedangkan untuk mengetahui kategori skor

keharmonisan keluarga karyawan perusahaan PT Asmin Koalindo Tuhup ditentukan interval skor dengan rumus :

$$
\begin{aligned}
& \frac{H-}{L}= \\
& R \\
& 4 \\
& \frac{4-\quad I}{=0.75}
\end{aligned}
$$

4
a. Sangat Harmonis
$: 4,2-4,9$
b. Harmonis
$: 3,4-$
4,I c. Cukup Harmonis
$: 2,6$
- 3,3 d. Kurang Harmonis
I,8 - 2,5 e. Sangat Kurang Harmonis :
$1-1,7$
Populasi dalam penelitian ini adalah seluruh

masyarakat kelurahan muara tuhup berjumlah 3.793 jiwa, yang terdiri dari 9 RT, sedangkan untuk suami yang sekarang bekerja sebagai karyawan perusahaan PT Asmin Koalindo Tuhup keseluruhannya hanya

27 orang dari Kelurahan Muara Tuhup, sedangkankaryawan yang berasal dari desa, kelurahan atau daerah lain juga banyak tetapi untuk lebih fokus dalam penelitian ini hanya karyawan yang berasal dari Kelurahan Muara Tuhup saja yang dapat di jadikan sampel penelitian. Adapun yang menjadi pilihan peneliti dalam menentukan sampel adalah menggunakan teknik sampling kouta. teknik ini digunakan untuk menentukan sampel dari populasi yang mempunyai ciri-ciri tertentu sampai jumlah(kouta) yang diinginkan. (Sugiyono :124) Maka dalam penelitian ini, dari jumlah sampel suami yang bekerja sebagai karyawan perusahaan PT Asmin Koalindo Tuhup yang ada di Kelurahan Muara Tuhup total keseluruhan berjumlah 27 orang itu diambil semua sebagai sampel dalam penelitian ini, karena total jumlah sampel tidak sampai dari

100-I50 subjek. Dari total keseluruhan tersebut untuk sampel tersebut terlebih dahulu mempuh beberapa persyaratan yang layak untuk dijadikan sampel, adapun beberapa syarat yang harus ditempuh sebelum di jadikan sampel adalah sebagai berikut:

I. Karyawan PT.Asmin Koalindo Tuhup yang masih aktif bekerja sebagai karyawan dan berdomisili di Kelurahan Muara Tuhup.

2. Karyawan PT.Asmin Koalindo Tuhup yang sudah berumah tangga atau berkeluarga, secara otomatis seorang karyawan yang belum berumah tangga atau berkeluarga tidak dapat dijadikan sebagai sampel dalam penelitian ini hal ini disesuaikan dengan judul penelitian penulis, karena bagaimana mungkin kita mengetahui keharmonisan keluarga jikalau karyawan itu belum berumah tangga atau berkeluarga.

Maka berdasarkan persyaratan yang harus dipenuhi tersebut diperolehlah karyawan PT Asmin Koalindo Tuhup yang berdomisili dan sudah berkeluarga / berumah tangga di kelurahan Muara Tuhup sebanyak II orang.

Penelitian ini menemukan bahwa I sampel pasangan suami istri memperoleh kategori harmonis dimana suaminya bekerja pada posisi supervisor/pengawas, 6 pasangan suami istri memperoleh kategori cukup harmonis dimana suaminya berkerja pada posisi Drive/supir, pasangan suami istri memperoleh kategori cukup harmonis dan 2 pasangan suami istri memperoleh kategori kurang harmonis dimana suaminya bekerja sebagai security/keamanan, I pasangan suami istri cleaning service/petugas kebersihan memperoleh kategori cukup harmonis. Jika dikalkulasikan secara keseluruhan yakni I sampel pasangan suami istri memperoleh kategori harmonis, 8 pasangan suami istri memperoleh kategori cukup harmonis, 2 pasangan suami istri memperoleh kategori kurang harmonis. Berdasarkan hasil uji statistik tentang korelasi antara pekerjaan suami dengan keharmonisan keluarga. Ternyata pekerjaan suami ada pengaruhnya terhadap keharmonisan keluarga, hal ini dapat dilihat dari hasil interpretasi harga $r x y$

$=0,594$ jika dikonsultasikan dengan rtabel $\mathrm{N}=22$ pada pada taraf signifikasi 5\% atau 0,05 diperoleh rtabel sebesar 0,423, sedangkan pada taraf signifikasi $1 \%$ atau 0,01 diperoleh rtabel sebesar

0,537 . Dengan demikian harga $r x y=0,59$ lebih besar dari rtabel, baik pada taraf signifikasi $5 \%$ atau $1 \%$ hal ini berarti interval koefisiennya berada pada 0,40

- 0,599 maka antara variabel $X$ dan variabel $Y$

menunjukkan tingkat hubungan yang cukup kuat.

Adapun konstribusi variabel $X$ terhadap variabel $Y$ diperoleh dengan hasil perhitungan koefisien determinansi (KD $=r 2 \times 100 \%)$ sebesar $35,28 \%$ hasil ini memberikan pemahaman bahwa variabel $X$ yakni pekerjaan suami memberikan konstribusi terhadap variabel $Y$ yakni keharmonisan keluarga sebesar 35 
8

$\%$.

Penelitian ini juga menemukan, antara pekerjaan suami dengan keharmonisan keluarga menunjukkan ada korelasi, yakni pekerjaan suami sebagai karyawan PT Asmin Koalindo Tuhup di Kelurahan Muara Tuhup berada pada interval skor kategori baik I sampel, cukup baik 6 sampel dan kurang baik 4 sampel. Sedangkan keharmonisan keluarga berada pada kategori harmonis I sampel, cukup harmonis 8 sampel dan kurang harmonis 2 sampel. Maka dapat disimpulkan tidak ada pasangan suami istri yang tingkat keharmonisannya berada pada level sangat harmonis. Hanya sebagian dari suami yang berkerja sebagai karyawan tingkat keharmonisannya berada pada level harmonis, dan sebagian yang lain cukup harmonis dan ada yang kurang harmonis. Adapun faktor penyebab darirendahnya tingkat keharmonisan keluarga antara lain

a) Banyaknya gaji dan bonus yang diperoleh setiap bulan oleh karyawan memberikan dampak yang signifikan terhadap keharmonisan keluarga. hal ini dibarengi juga dengan manajemen pengelolaan anggaran pendapatan dan pengeluaran keuangan keluarga yang tertata baik serta teratur. Jika pendapatan gaji besar serta manajemen pengelolaan keuangan keluarga bagus maka tingkat keharmonisan keluarga menunjukkan nilai positif, sebaliknya jika gaji kecil serta manajemen pengelolaan keuangan kurang baik niscaya tingkat keharmmonisan keluarga menujukkan nilai negatif.

b) Tingkat pengetahuan, intelektual atau pendidikan dari suami dan istri dalam keluarga. dalam hal ini jika semakin tinggi pendidikan suami atau istri maka semakin tinggi atau bagus tata kelola kehidupan berkeluarganya.

c) Lingkungan. Dalam hal ini jika suami atau istri tidak pandai dalam menjalankan kehidupan

keluarganya supaya tidak ikut terkontaminasi dampak lingkungan yang tidak baik niscaya hal inipun berpengaruh terhadap tingkat keharmonisan keluarga.

d) Sebagaimana telah dijelaskan pada kajian teori, bahwa ibadah spiritual atau relegiusitas dalam keluarga perlu untuk ditumbuhkan, sehingga semakin sering frekuensi ibadah spiritual atau relegiusitas suami atau istri bersama-sama keluarganya tentu berdampak baik terhadap keharmonisan keluarga.

Selain 4 faktor di atas, terdapat faktor lain lagi yang menjadi sebab rendahnya tingkat keharmonisan keluarga yakni tidak terpenuhi atau terlaksananya hak dan kewajiban suami atas istri juga hak dan kewajiban istri atas suami yang akan penulis jelaskan menurut Kompilasi Hukum Islam sebagai berikut:

a. Dalam Kompilasi Hukum Islam pasal 80 ayat (I) bahwa suami adalah pembimbing terhadap istri dan rumah tangganya, akan tetapi mengenai halhal urusan rumah tangga yang penting-penting diputuskan oleh suami istri bersama. Ayat (3) bahwa suami wajibmemberi pendidikan agama kepada istrinya dan memberi kesempatan belajar pengetahuan yang berguna dan bermanfaat bagi agama nusa dan bangsa.

Pada pasal 80 ayat (I) ini berdasarkan hasil jawaban angket penelitian dan pengamatan penulis bahwa seorang suami yang berprofesi sebagai karyawan perusahaan PT Asmin Koalindo Tuhup seharusnya membimbing istri dan rumah tangganya, tetapi dikarenakan sibuk dengan pekerjaan sehingga alokasi waktu untuk bersama keluarga dirumah hanya digunakan oleh suami untuk beristirahat sebagai persiapan berangkat kerja lagi sehingga hak dan kewajiban suami pada pasal 80 ayat (I) Kompilasi Hukum Islam ini belum sepenuhnya dilaksanakan oleh pihak suami. Seharusnya seorang suami ketika berada di rumah memanfaatkan waktu tidak hanya untuk istirahat sebagai persiapan berangkat kerja lagi tetapi lebih dari itu seorang suami sebagai pembimbing terhadap istri dan rumah tangganya lebih pro aktif terhadap keadaan keluarganya.

Pada pasal 80 ayat (3) ini seorang suami seharusnya meluangkan waktu bersama istri dan keluarganya untuk mempelajari pengetahuan dan pendidikan agama, karena ini adalah hak dan kewajiban suami atas istri. Berdasarkan hasil angket penelitian dan pengamatan penulis pada kenyataannya tidak demikian. Seorang suami hanya memikirkan bagaimana memajukan kesejahteraan finansial keluarganya tapi lalai memberikan pendidikan agama kepada istri dan keluarganya, hal ini bisa bertambah parah bila seorang istri tidak faham dengan kondisi suaminya dan mengabaikannya.

b. Dalam Kompilasi Hukum Islam pasal 83 ayat (2) bahwa istri menyelenggarakan dan mengatur keperluan rumah tangga sehari-hari. Pada pasal ini hak dan kewajiban seorang istri atas suami bahwa istri menyelenggarakan dan mengatur keperluan rumah tangga sehari-hari, jika istri tidak menunaikan kewajiban ini terhadap suami maka istri dianggap nusyuz. Berdasarkan hasil angket penelitian menunjukkan bahwa sebagian istri lalaimenunaikan hak dan kewajibannya terhadap suami. Hal ini di tambah pula suaminya tidak mengambil tindakan tegas terhadap istrinya, hanya membiarkan keadaan seperti ini berlanjut terus menerus.

\section{KESIMPULAN}

Berdasarkan hasil penelitian dan pembahasan maka disimpulkan bahwa: 
I. Keharmonisan keluarga pada karyawan yang interval skor dengan kategori Harmonis sebanyak I sampel yang beposisi sebagai Supervisor, Cukup Harmonis 8 sampel yang berposisi sebagai Driver 6 orang, Security I orang, Cleaning Service I orang dan Kurang Harmonis 2 sampel yang berposisi sebagai Security 2 orang.

2. Dari perhitungan analisis korelasi dan diuji dengan perhitungan uji $t$ serta dihitung dengan rumus Koefisien Determinasi menunjukkan bahwa antara pekerjaan suami sebagai karyawan perusahaan PT Asmin Koalindo Tuhup dengan kehamonisan keluarga tedapat korelasi, pekerjaan suami memberi pengaruh cukup kuat terhadap keharmonisan keluarga

\section{DAFTAR PUSTAKA}

Alsa, Asmadi, Pendekatan Kuantitatif dan Kualitatif serta Kombinasinya Dalam Penelitian Psikologi, Yogyakarta : Pustaka Belajar, 2003

Basri, Hasan, Merawat Cinta Kasih. Yogyakarta: Pustaka Pelajar, 1996

- Keluarga Sakinah Tinjauan Psikologi dan Agama. Yogyakarta; Pustaka pelajar, 2002

Dlaifurrahman, Muhammad, "Upaya Membangun Keluarga Sakinah", Jurnal Hadratul Madaniyah, Volume 4 Issue I, Juni 2017

Dlori, Muhammad. M, Dicintai Suami (istri) Sampai Mati, Jogjakarta: Katahati, 2005

Dradjat, Zakiah, Ketenangan dan Kebahagiaan Dalam Keluarga, Jakarta: Bulan Bintang, 1975

D. Gunarsa, Singgih dan Yulia Singgih D. Gunarsa, Psikologi Praktis Anak Remaja dan Keluarga. Jakarta: Gunung Mulia. 1991

, Psikologi untuk Keluarga. Jakarta: Gunung Mulia. 1986

Doe, Mimie, SQ Untuk Ibu: Cara-Cara Praktis dan Inspiratif Untuk Mewujudkan Ketentraman Ruhani, Bandung: Penerbit Kaifa, 2002

Elizabet. B, Hurlock, Psikologi Perkembangan, Suatu Pendekatan Sepanjang Rentang Kehidupan. Jakarta: Erlangga, 1999

Hawari, Dadang, Al-Qur'an: Ilmu Kedokteran Jiwa dan Kesehatan Jiwa, Yogyakarta: Dana Bakti Prima Yasa, 2004

Manan, Abdul, Aneka Masalah Hukum Perdata Islam di Indonesia, Jakarta: Kencana, 2008

Martono, Nanang, Metode Penelitian Kuantitatif, Jakarta: PT RajaGrafindo Persada, 2011, cetakan ke-2
Tangga. Bogor: Cahaya, 2004.

Ariyadi, Ariyadi. "Tindak Pidana Pelaku Eksploitasi Seksual pada Anak Menurut Hukum Islam." Jurnal Hadratul Madaniyah 6.1 (2019): 43-67.

Sanawiah, Sanawiah. "Pengalihan Hak Hadhanah Jatuh kepada Bapak terhadap Anak Belum Mumayyiz (Studi Kasus di Pengadilan Agama Palangka Raya)." Anterior Jurnal 18.2 (2019): 158162. 